\title{
RESEARCH NOTE \\ Molecular characterization of Lotus corniculatus cultivars using transferable microsatellite markers
}

\author{
Diego Alem¹, Rafael Narancioํㅜ, Paola Díaz Dellavalle, Mónica Rebuffo², \\ Rodrigo Zarza ${ }^{2}$, and Marco Dalla Rizza ${ }^{1}$ \\ ${ }^{1}$ Unidad de Biotecnología, Instituto Nacional de Investigación Agropecuaria (INIA Las Brujas). Ruta 48 \\ Km.10. Canelones, Uruguay. \\ ${ }^{2}$ Programa Nacional de Pasturas y Forrajes, Instituto Nacional de Investigación Agropecuaria (INIA La \\ Estanzuela). Ruta $50 \mathrm{Km} .11$. Colonia, Uruguay.
}

\begin{abstract}
D. Alem, R. Narancio, P. Díaz Dellavalle, M. Rebuffo, R. Zarza, and M. Dalla Rizza. 2011. Molecular characterization of cultivars of Lotus corniculatus using transferable microsatellite markers. Cien. Inv. Agr. 38(3): 453-461. Lotus corniculatus L. is the most important agricultural species in the genus Lotus and is the most widely distributed Lotus species worldwide. L. corniculatus genotypes form complex groups that are difficult to recognize both morphologically and biochemically. Given the extensive and expensive process of isolating Simple Sequence Repeats (SSR, also called microsatellites), the possibility of using microsatellites already identified in related species is highly attractive. The aim of this work was the identification and validation of transferable microsatellite markers in L. corniculatus, and using those markers to study the genetic variability among four cultivars. Each cultivar of $L$. corniculatus was represented by 15 genotypes. Ten microsatellite markers were evaluated, and from those, four were selected based on their discriminative values observed among cultivars. We detected 29 alleles for the four markers, and there was an average of 7.25 alleles per locus. The marker TM0197 had the fewest number of alleles (5) and TM0083 had the highest number of alleles (10). The polymorphic information content (PIC) for the selected markers varied from 0.19 to 0.35 , and the markers were therefore classified as highly informative. Based on the markers, we found high variability between individuals of the same cultivar. The use of transferable microsatellite markers could be useful to differentiate individuals at a relatively low cost, showing a great potential for use in breeding programs.
\end{abstract}

Key words: Genetic variability, Lotus japonicus, SSR.

\section{Introduction}

Lotus corniculatus $\mathrm{L}$. is the most important and widely distributed crop from the Lotus genus (Díaz et al., 2005). L. corniculatus is a warm-season cross-pollinating legume forage species that is

Received September 7, 2010. Accepted June 21, 2011. Corresponding author: mdallarizza@inia.org.uy perennial and tetraploid $(2 n=4 x=24)$ (though there are some reports of diploid plants) (Grant and Small, 1996). Although the species originated in temperate areas of Europe and north Africa, it has spread throughout Europe, Asia, Africa, North and South America, Australia and New Zealand as a result of cultivation for use in pastures, ensilage and hay production (Duke, 1981; Beuselinck and Grant, 1995; Ayala and Carámbula, 2009). 
L. corniculatus has several important traits that make it attractive as an agricultural species. For example, it is adaptable to relatively extreme environments, such as acidic and poorly drained soils (Duke, 1981; Beuselinck and Grant, 1995; Ayala and Carámbula, 2009). Additionally, it has a high nutritive value for grazing, and does not produce bloat in cattle (Carámbula, 1977; Ramírez-Restrepo and Barry, 2005; Ayala and Carámbula, 2009).

In Uruguay, the most frequently used cultivars of L. corniculatus are as follows: (1) San Gabriel, which was originated from a population from Rio Grande do Sul (Brazil); (2) Estanzuela Ganador, which is a selection of FAO lines originally introduced from Argentina; (3) INIA Draco, which was derived from crosses of Estanzuela Ganador and a population from eastern Uruguay (Colonia department, Uruguay) after two rounds of recurrent selection; and (4) Rigel, which was obtained after two more rounds of selection from INIA Draco.

Microsatellites are considered to be a useful genetic marker system because they are abundant sequences, highly polymorphic, locus specific, multiallelic, codominant and robust (Weber, 1990; Morgante and Olivier, 1993). The major disadvantage of the use of this marker is its high development cost (Zane et al., 2002; Squirrel et al., 2003; Saha et al., 2006). To overcome this problem, it is sometimes possible to transfer knowledge of microsatellite markers already developed in well-known species to less studied species. Given the vast information on microsatellites available in the literature and in genetic databases, markers developed in species related to those of interest can be searched and tested. This makes it possible to circumvent marker development, which makes the use of microsatellite easier and cheaper (Peakall et al., 1998; Dalla Rizza et al., 2005; Real et al., 2007).

The cross amplification of microsatellite markers among species can improve as the phylogenetic distance decreases (Peakall et al., 1998). For example, Peakall et al. (1998) reported the transferable use of SSR markers from soy (Glycine max) for other members of the Fabaceae family. The amplification observed among different genera of Fabaceae was between 3 and $13 \%$, while there was $65 \%$ amplification among species from the genus Glycine (Peakall et al., 1998). Similar results were obtained using transferable microsatellite markers in tall fescue (Festuca arundinacea Schreb.), wheat (Triticum aestivum L.), ryegrass (Lolium multiflorum Lam.) and rice (Oriza sativa L.) (Saha et al., 2006).

Generally, L. corniculatus genotypes tend to form highly related complexes which are difficult to define, both biochemically and morphologically (Steiner and Poklemba, 1994). Although there are few examples of the use of molecular markers in L. corniculatus, those that are available report high genetic variability. $L$. corniculatus populations have been evaluated using isoenzyme (e.g., cyanogen) reactions (Blaise et al., 1991), globulin electrophoretic profiles (Steiner and Poklemba, 1994), RAPD markers to assess relatedness among Lotus species (Campos et al., 1994; Steiner and García de los Santos, 2001; García de los Santos and Steiner, 2003), inheritance studies with RAPD and RFLP markers (Fjellstrom et al., 2001) and AFLP and microsatellite markers in natural populations (Savo Sardaro et al., 2008). High intra-population variability and even higher inter-population variability was observed within and among natural populations in Italy using potentially transferable microsatellite markers that were useful for accession discrimination (Savo Sardaro et al., 2008).

The purpose of this study was to develop and modify molecular tools for the characterization of $L$. corniculatus cultivars using transferable microsatellite markers from L. japonicus, and to assess the intra- and inter-cultivar variability among four cultivars. 


\section{Materials and methods}

\section{Plant material}

Fifteen individuals from each cultivar (San Gabriel, Draco, Ganador and Rigel) were used in this study. Lotus japonicus individuals were used as positive reference controls (three genotypes each of Miyakojima MG-20 and Gifu B-129). Genomic DNA was extracted according to the protocol of Doyle and Doyle (1987).

Ten primers previously developed in L. japonicus (Sato et al., 2001) were used for this assay. Annealing temperatures were adjusted with gradient PCR in a Palm cycler CG1-96 (Corbett Research, Australia). Four primers were selected from the 10 evaluated based on their repeatability, polymorphic content and sharpness of the bands obtained in polyacrilamide gels (Table 1). PCR reactions were performed under the following conditions: $20 \mu \mathrm{L}$ of total volumen reaction, 40 $80 \mathrm{ng}$ of genomic DNA, reaction buffer $-75 \mathrm{mM}$ Tris- $\mathrm{HCl}, 50 \mathrm{mM}$ of $\mathrm{KCl},\left(\mathrm{NH}_{4}\right)_{2} \mathrm{SO}_{4} 20 \mathrm{mM}$-, $1.0 \mathrm{mM}$ of $\mathrm{MgCl}_{2}, 100 \mu \mathrm{M}$ of dNTPs, $1.0 \mu \mathrm{M}$ of each primer, and 1.0 U Taq polymerase (Biotools). PCR was programmed for $4 \mathrm{~min}$ of initial melting at $94{ }^{\circ} \mathrm{C}$, followed by 30 cycles each at $94{ }^{\circ} \mathrm{C}$ for $30 \mathrm{~s}$, annealing temperatures between $53{ }^{\circ} \mathrm{C}$ and $60^{\circ} \mathrm{C}$ (depending on the primer) (Table 1) for $20 \mathrm{~s}, 72{ }^{\circ} \mathrm{C}$ for $20 \mathrm{~s}$, and a final extension step at $72{ }^{\circ} \mathrm{C}$ for $7 \mathrm{~min}$. Amplification products were run on denaturing $8 \%$ polyacrylamide gels (Urea 7.0 M, TBE buffer 1X, Bio-rad Sequi-Gen GT Nucleic Acid Electrophoresis Cell, USA) for approximately $90 \mathrm{~min}$. The bands were visualized using the silver stain method (Tixier et al., 1997).

\section{Analysis}

Sets of primers where there was no amplification, or when amplification was weak or illegible, were discarded. The staining method used was not quantitative, and therefore the allelic dose inferred by the banding intensity was not considered. The presence of null alleles is another source of error when trying to determine allelic dosage. A null allele results from a mutation in the region of DNA where the primers hybridize, leading to a consequent lack of the corresponding band (Luo et al., 2000); null alleles are more common in plants with a polysomal inheritance than_in diploids (Luo et al., 2000). There are several precedents in polyploid species where microsatellites are considered as dominant markers to overcome these limitations (Mengoni et al., 2001; George et al., 2006). This approach was adopted for the analysis considering the microsatellite-transferable elements obtained as dominant markers, and it was assumed that each band corresponds to a locus with two alleles. Band presence (1) or absence (0) was determined visually. Band sizes were determined by comparisons with the reference microsatellite alleles known from L. japonicus (Miyakojima MG-20 and Gifu B-129) and 100 bp (molecular weight) markers (Invitrogen, Table 1).

To determine the genetic distances between plants, a binary matrix was constructed and a Jaccard similarity coefficient calculated.

$$
J=\frac{b+c}{a+b+c}
$$

where:

$a=$ number of bands present in $x i$ and $x j$ $b=$ number of bands present in $x i$ and absent in $x j$ $\mathrm{c}=$ number of bands present in $\mathrm{xj}$ and absent in $\mathrm{xi}$, where $x i$ and $x j$ are the $i$-th and $j$-th individuals.

Cluster analysis was performed using the NeighborJoining (NJ) method, which is based on finding neighbors sequentially to minimize the total tree length (Saitou and Nei, 1987). In this study we used the Gascuel (1997) version, which uses the weighted average to calculate the Unweighted Neighbor-Joining (UNJ) (Gascuel, 1997). The genetic similarity matrix was performed using the software DARWIN 5.0 (Darwin softwarehttp:// darwin.cirad.fr/darwin). The dendrogram is a branching description of the similarity or genetic distance between individuals. We also carried out 
Table 1. Microsatellites markers evaluated in this work.

\begin{tabular}{|c|c|c|c|c|c|}
\hline \multirow[b]{2}{*}{ Marker name } & \multirow{2}{*}{$\begin{array}{l}\text { SSR motif } \\
\begin{array}{l}\text { Number of } \\
\text { repeats }\end{array}\end{array}$} & \multirow{2}{*}{$\begin{array}{l}\text { Forward primer (5' to 3') } \\
\text { Reverse primer (5' to 3') }\end{array}$} & \multicolumn{2}{|c|}{$\begin{array}{l}\text { Band size in Lotus } \\
\text { japonicus }\end{array}$} & \multirow{2}{*}{$\begin{array}{c}\begin{array}{c}\text { Annealing } \\
\text { temperatures }\end{array} \\
\left({ }^{\circ} \mathrm{C}\right)\end{array}$} \\
\hline & & & MG-20 & B-129 & \\
\hline TM0197' & $(\mathrm{AAC})_{8}$ & $\begin{array}{l}\text { CATTCACATGTCATTGGACC } \\
\text { TTAGATCGAGTTCGAGGGAG }\end{array}$ & 121 & 119 & 56 \\
\hline TM0304 & $(\mathrm{CT})_{18}$ & $\begin{array}{l}\text { CGTTCTCTGGGAACTTATGAC } \\
\text { ATTTGTTGTGTGCACTCAGG }\end{array}$ & 127 & 115 & NA \\
\hline TM0212 & $(\mathrm{CT})_{13}$ & $\begin{array}{l}\text { CTTCCTTCCTCACCACTTAG } \\
\text { TAAACGAAAATGAAGCAGAG }\end{array}$ & 153 & 159 & 57 \\
\hline $\mathrm{TM}^{2} 023^{1}$ & $(\mathrm{AT})_{12}$ & $\begin{array}{l}\text { CTGTTTTGACGAATCGATAG } \\
\text { TACGAAGGTTTCTTCATTCC }\end{array}$ & 151 & 179 & 56 \\
\hline TM00232 & $(\mathrm{AT})_{12}$ & $\begin{array}{l}\text { CATAAGCACAACAATTCATAG } \\
\text { GTTGTGGTTCAAAGTTAGGG }\end{array}$ & 185 & 179 & 53 \\
\hline $\mathrm{BM} 1397^{3}$ & $(\mathrm{AT})_{8+11}$ & $\begin{array}{l}\text { ATTCAGTAACAGAAATCCCG } \\
\text { AAAGACTCGAGACCAATACC }\end{array}$ & 180 & 200 & 53 \\
\hline $\mathrm{TM}^{2} 083^{1}$ & $(\mathrm{CT})_{19}$ & $\begin{array}{c}\text { CTCTCTCTCAGGGCCAACAC } \\
\text { TGATTCTTGAAGATTTAAAAGATG }\end{array}$ & 161 & 148 & 59 \\
\hline TM1335 & $(\mathrm{CT})_{9}$ & $\begin{array}{l}\text { ATTAGACCACCACGGGCTGC } \\
\text { CCAAAGTTACTCAATGTAGCG }\end{array}$ & 153 & 155 & NR \\
\hline TM1150 & $(\mathrm{CT})_{9}$ & $\begin{array}{l}\text { ATCCAGAAACTCCATCCAAG } \\
\text { TCGTTTTCAAACTGTCATCG }\end{array}$ & 156 & 162 & NR \\
\hline TM0360 & $(\mathrm{AT})_{10+17}$ & $\begin{array}{l}\text { CATGCTTGGAATGTTACTGC } \\
\text { GTGTATTGGATGTTATGGGG }\end{array}$ & 113 & 95 & NA \\
\hline
\end{tabular}

${ }^{1}$ primers used in this work.

${ }^{2}$ Monomorphic.

${ }^{3}$ Band patterns were not legible.

NR, not repeatable. NA, no amplification detected. MG-20 and B-129, Lotus japonicus lines.

Adapted from http://www.kazusa.or.jp/lotus/

a principal coordinates analysis (PCA) using the similarity matrix. PCA is a multivariate technique used to find the dominant patterns in a multivariate dataset.

The genetic similarity matrix was used in an analysis of molecular variance (AMOVA) to estimate the variability within and between cultivars. AMOVA partitions, and therefore estimates, the total variance components (Excoffier et al., 1992). This analysis was performed using GenAlEx
6.2 (Australian National University, Canberra, Australia).

The polymorphism information content (PIC) was calculated as: $\mathrm{PIC}=1-\sum \mathrm{P} i$, where $\mathrm{P} i$ is the band frequency of the i-th allele. For dominant marker values, $\mathrm{PIC}=1-\mathrm{p}^{2}-\mathrm{q}^{2}$, where $\mathrm{p}=$ band frequency and $\mathrm{q}=$ no-band frequency (Ghislain et al., 1999). The PIC value represents the possible combinations between the different alleles and is an index of the informative capacity of the microsatellite marker. 


\section{Results and discussion}

Eight of the 10 tested primers amplified, demonstrating the transferability of markers to L. corniculatus (Table 1). Four markers, TM0083, TM0212, TM0197 and TM0203, were selected according to the above-mentioned criteria. We obtained amplification products with the TM0083, TM0197 and TM0212 primers for all of the individual plants tested. The TM0203 primer did express alleles for plants 10 and 3 from Estanzuela Ganador and INIA Draco, respectively. The other six primers showed weak patterns, which made the analysis difficult. This was not surprising, since primers from different species do not always show strong patterns. Accounting for the genetic background of the studied cultivars, the high variability of the microsatellite sequences made it possible to find differences between plants with a low genetic diversity (see also Peakall et al., 1998). Mutations could cause the emergence of null alleles or the fading of microsatellite sequences, which leads to bands that do not amplify.

Twenty-nine alleles were found from the visual analysis of the polyacrilamyde gels (Figure 1). The maximum number of alleles per plant considered was 4 . The average number of allele per locus was 7.25. TM0197 had the fewest alleles (5) while TM0083 had the highest number of alleles (10) (Table 2). Savo Sardaro et al. (2008) analyzed 88 plants from 11 L. corniculatus in Italy with microsatellite markers (the TM0083, TM0212, and TM0203 markers were also used here), and reported a higher number of alleles (68) and also a higher average of alleles per locus (13.6) than found here. These different results could have been because Savo Sardaro et al. studied natural populations from different locations, while cultivars with a lower expected variability were studied here. In addition, the number of plants analyzed in the current study was lower than in the study by Savo Sardaro et al. (60 vs. 88), and therefore the probability of finding more alleles should be also lower.

Table 2. Number of alleles and PICs value obtained for the markers used. Sixty plants per primer were analyzed (15 plants per cultivar).

\begin{tabular}{lcc}
\hline Marker & Number of alleles & PIC \\
\hline TM0212 & 6 & 0.19 \\
TM0083 & 10 & 0.28 \\
TM0203 & 8 & 0.35 \\
TM0197 & 5 & 0.23 \\
Average & 7.25 & 0.26 \\
\hline
\end{tabular}

The polymorphic information content (PIC) results are listed in Table 2. The PIC, which is equivalent to Nei's genetic diversity index, is frequently used to evaluate the discriminatory power of a microsatellite locus (Roussel et al., 2004; George et al., 2006). This is based on the expected heterozygocity and the allele frequencies (Botstein and White, 1980). There is more than one equation that defines the PIC, and the value ranges between 0 and 1 . Because the microsatellite markers were scored as dominant, the maximum PIC value should be between 0.01 and 0.5 . Higher PIC values indicate

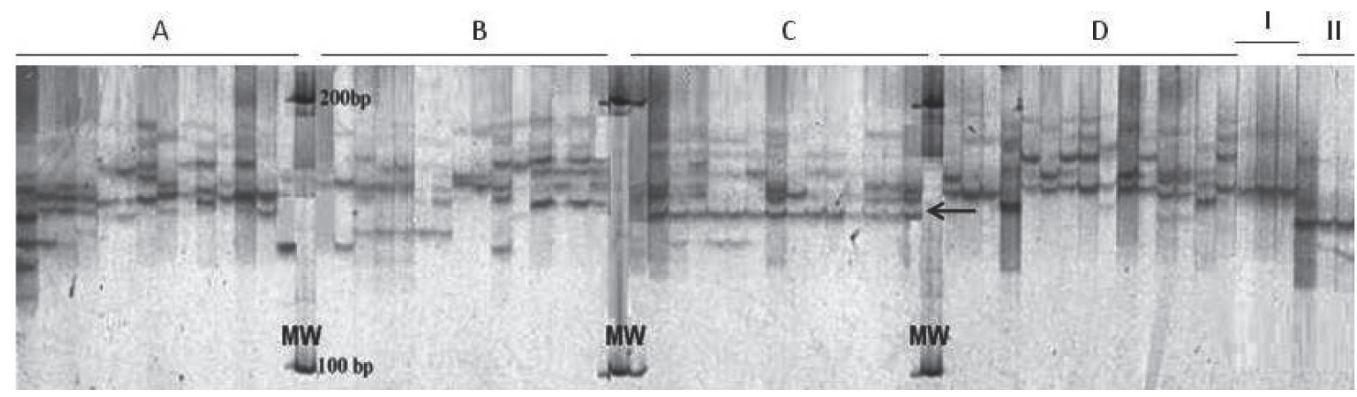

Figure 1. Polyacrilamide denaturing gel (8\%) obtained with the TM0083 primer. The arrow points to a band primarily present in the San Gabriel cultivar. A: INIA Draco; B: Estanzuela Ganador; C: San Gabriel; D: Rigel. I: Miyakojima MG20 and II: Gifu B-12. MW: Molecular weight marker. 
more informative content (Ghislain et al., 1999). The average PIC value for all the evaluated loci was 0.26 . The maximum PIC value was 0.35 (TM0203) and the lowest was 0.19 (TM0212).

The AMOVA evaluated the distribution of genetic variance both within and among cultivars. Eighty-two percent of the variance was explained by the within-cultivar genetic differences, while $18 \%$ was explained by the among-cultivar differences. The high within-cultivar variability found in this study is consistent with others studies of allogamous plants (Rajasekar S. et al., 2005). This could make the cultivar differentiation difficult with the primers used. Thus, to find informative markers, it is necessary to test a higher number of primers in order to differentiate cultivars.

\section{Line grouping}

A genetic distance matrix was calculated using the Jaccard's coefficient and a grouping analysis was performed. There was a tendency of associa- tion between individuals from the San Gabriel cultivar, but there was no clear association pattern for individuals of the other cultivars (Figure 2). In fact, as mentioned above, San Gabriel has a genetic background from Rio Grande do Sul (Brasil), which is geographically far from the other cultivars analyzed. The explanation for the lack of differentiation observed among the Estanzuela Ganador, INIA Draco and Rigel cultivars could be that the INIA Draco and Rigel lines were both obtained from the Estanzuela Ganador cultivar. Similar results were obtained from the PCA, in which there was no discernable pattern among individuals (results not shown). There is generally a high rate of gene flow and germplasm exchange among allogamous plants, which could explain these results. The close origin of the cultivars supports this tendency. Although none of the cultivars could be differentiated, we found some band association in the San Gabriel cultivar.

To conclude, the molecular markers used in this study confirmed the high allelic variability within and among the L. corniculatus cultivars

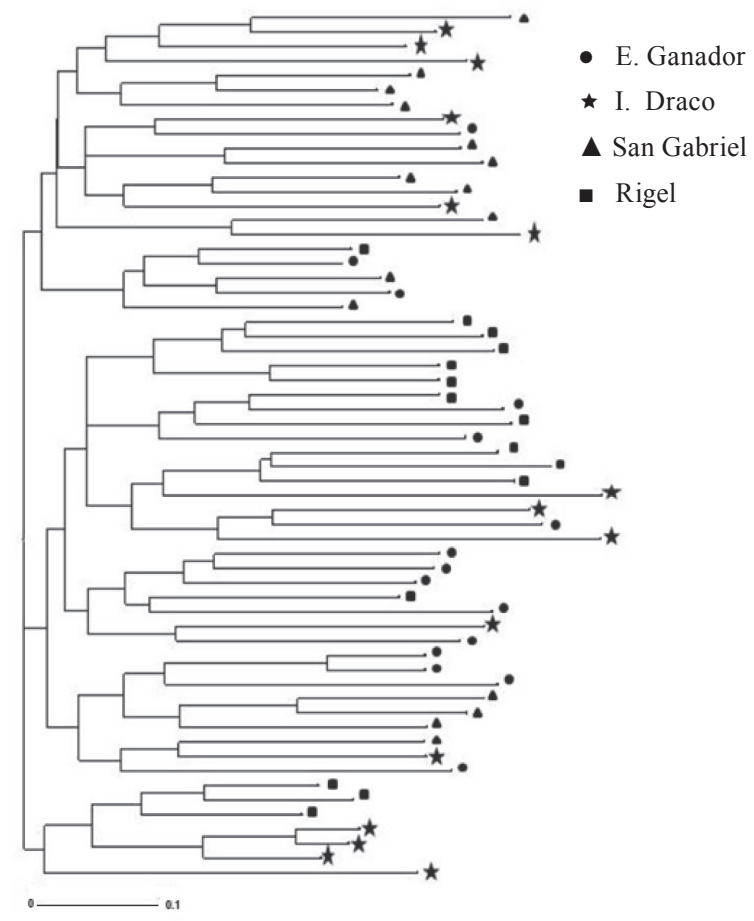

Figure 2. Dendrogram for the 60 Lotus corniculatus genotypes obtained from the Unweighted Neighbour joining (UNJ) analysis. 
evaluated. Further, a higher number of markers would likely permit the discrimination among the four cultivars. Regardless, the markers used in this study could be useful for differentiating less closely related populations of $L$. corniculatus, or for distinguishing L. corniculatus from other related Lotus species.

The use of transferable microsatellite markers has been shown to be a promising tool for biodiversity evaluation and for breeding $L$. corniculatus germplasm. Transferable microsatellites were reproducible and fast, with a relatively low cost.
In addition, this study shows that the transfer of microsatellite markers from molecularly wellknown species to agronomically important species with little sequence information is feasible.

\section{Acknowledgements}

The authors wish to thank Guillermo Galván, from the Faculty of Agronomy (UdelaR-Uruguay), for his comments and suggestions. This research was funded in part by Fontagro Project, LESISFTG-187/2005.

\section{Resumen}

D. Alem, R. Narancio, P. Díaz Dellavalle, M. Rebuffo, R. Zarza y M. Dalla Rizza. 2011. Caracterización molecular de cultivares de Lotus corniculatus mediante el empleo de marcadores microsatélites transferibles. Cien. Inv. Agr. 38(3): 453-461. Lotus corniculatus L. es la especie de mayor importancia agronómica en el género Lotus y la de mayor distribución a nivel mundial. Los genotipos de L. corniculatus forman grupos genéticos complejos y difíciles de reconocer tanto morfológica como bioquímicamente. Dado el proceso largo y costoso de aislar secuencias simples repetidas (SSR, microsatélites), resulta altamente atractiva la posibilidad de utilizar microsatélites ya identificados en una especie relacionada. El objetivo del trabajo fue la identificación y validación de marcadores microsatélites transferibles y la caracterización molecular de cuatro cultivares. Cada cultivar de L. corniculatus fue representado por 15 genotipos. Se evaluaron 10 marcadores microsatélites provenientes de L. japonicus L. Se comprobó la transferibilidad de marcadores de L. japonicus en L. corniculatus. Se detectaron un total de 29 alelos para los 4 microsatélites trasferibles seleccionados, mientras que el promedio de alelos por locus fue de 7,25. El marcador TM0197 fue el que menos alelos presentó (5 alelos) y el TM0083 el que más presentó (10 alelos). El contenido de información polimórfica (PIC) para los marcadores seleccionados varió entre 0,19 y 0,35 calificando en el rango de altamente informativos. Se comprobó una alta variabilidad entre individuos del mismo cultivar. El empleo de marcadores microsatélites puede ser de gran utilidad para diferenciar individuos a un bajo costo, presentando un gran potencial para su uso en mejoramiento.

Palabras clave: Lotus corniculatus, SSR, variabilidad genética.

\section{References}

Ayala, W., and M. Carambula. 2009. El valor agronómico del género Lotus. Ediciones INIA, Montevideo, Uruguay. 424 pp.

Beuselinck, P.R., and W.F. Grant. 1995. Birdsfoot trefoil. In: R. F. Barnes, D. A. Miller and C. J. Nelson (eds.) Forages. An introduction to grass- land agriculture. State Univ. Press, Ames, Iowa, USA. 5th ed. p. 237-248.

Blaise, S., D. Cattier, and J. Reynaud. 1991. Evolution and differentiation of Lotus corniculatus I. Lotus alpinus populations from the French southwestern Alps. I. Morphological and cyanogenic variations. Evol. Trends Plants 5: 137-148.

Botstein, D., and R.L. White. 1980. Construction of 
a genetic linkage map in man using restriction fragment lenght polymorphism. American Journal of Human Genetics 32: 314-331.

Campos, L.P., J.V. Raelson, and W.F. Grant. 1994. Genome relationships among Lotus species based on random amplified polymorphic DNA (RAPD). Theor. Appl. Genet. 88: 417-422.

Carámbula, M. 1977. Producción y manejo de pasturas sembradas. Edit. Hemisferio Sur. Montevideo. 464 pp.

Dalla Rizza, M., D. Real, R. Reyno, and K.H. Quesenberry. 2005. Use of cross-species amplification markers for pollen-mediated gene flow determination in Trifolium polymorphum Poiret. In: M.O. Humphreys (ed.) Molecular breeding for the genetic improvement of forage crops and turf. Proc. of the 20th Int. Grassland Congr., Aberystwyth, Wales. Wageningen Academic Publishers, Wageningen, the Netherlands. p. 194.

Díaz, P., O. Borsani, and J. Monza. 2005. Lotus-related species and their agronomic importance. A.J. Márquez, Stougaard J., Udvardi M., Parniske M., Spaink H., Saalbach G., Webb J., Chiurazzi M. (eds.). Lotus Japonicus Handbook. Springer p. 25-37.

Doyle, J.J., and J.L. Doyle. 1987. A rapid DNA isolation procedure for small quantities of fresh leaf tissue. Phytochemistry Bulletin 19: 11-15.

Duke, J.A. 1981. Handbook of legumes of world Economic importance. Plenum press, New York, USA. 345 pp.

Fjellstrom, R.G., P.R. Beuselinck, and J.J. Steiner. 2001. RFLP marker analysis supports tetrasomic inheritance in Lotus corniculatus L. Theor. Appl. Genet. 102: 718-725.

García de los Santos, G., and J.J. Steiner. 2003. Diversidad genética en Lotus Corniculatus determinada por caracteres morfológicos y RADPs. Rev. Fítotec. Mex. 26: 173-181.

Gascuel, O. 1997. Concerning the NJ algorithm and its unweighted version, UNJ. American Mathematical Society 37: 149-170.

George, J., M.P. Dobrowolski, E. van Zijll de Jong, N. Cogan, K.F. Smith, and J.W. Forster. 2006. Assessment of genetic diversity in cultivars of white clover (Trifolium repens L.) detected by SSR polymorphisms. Genome 49: 919-930.

Ghislain, M., Zhang, D., Fajardo, D., Huaman, Z., and Hijmans, R.J. 1999. Marker-assisted sampling of the cultivated Andean potato Solanum phureja collection using RAPD markers. Genetic Resources and Crop Evolution 46: 547-555
Grant, W.F., and E. Small. 1996. The origin of Lotus corniculatus (Fabaceae): A synthesis of diverse evidence. Can. J. Bot. 74: 975-989.

Luo, Z.W., C.A. Hackett, J.E. Bradshaw, J.W. Mc Nicol, and D. Milbourne. 2000. Predicting parental genotypes and gene segregation for tetrasomic inheritance. . Theor. Appl. Genet. 100: 10671073.

Mengoni, A., A. Gori, and M. Bazzicalupo. 2001. Use of RAPD and microsatellite (SSR) variation to assess genetic relationships among populations of tetraploid alfalfa, Medicago sativa. Plant Breed. 119: 311-317.

Morgante, M., and A.M. Olivier. 1993. PCR-amplified microsatellites as markers in plant genetics. The Plant Journal 3: 175-182.

Nei, M. 1987. Molecular Evolutionary Genetics. Columbia University Press, New York, USA. 512 pp.

Peakall, R., S. Gilmore, W. Keys, M. Morgante, and A. Rafalski. 1998. Cross species amplication of soybean (Glycine max) simple sequence repeat (SSRs) within the genus and other legume genera: Implications for transferability of SSRs in plants. Mol. Biol. Evol. 15: 1275-1287.

Ramírez-Restrepo, C.A., and T.N. Barry. 2005. Alternative temperate forages containing secondary compounds for improving sustainable productivity in grazing ruminants. Animal Feed Science and Technology 120: 179-201.

Real, D., M. Dalla Rizza, R. Reyno, and K. Quesenberry. 2007. Breeding system of the aerial flowers in an amphicarpic clover species: Trifolium polymorphum. Crop Science 47: 1401-1406.

Roussel, V., J. Koenig, M. Beckert, and F. Balfourier. 2004. Molecular diversity in French bread wheat accessions related to temporal trends and breeding programmes. Theor. Appl. Genet. 108: 920-930.

Saha, M.C., J.M. Cooper, M.A. Rouf Mian, K. Chekhovskiy, and G.D. May. 2006. Tall fescue genomic SSR markers: development and transferability across multiple grass species. Theor. Appl. Genet. 113: 1449-1458.

Saitou, N., and M. Nei. 1987. The Neighbor-Joining method: a new method for reconstructing phylogenetic trees. Molecular Biology and Evolution 4: 406-425.

Sambrook, J., E.F. Fritsch, and T. Maniatis. 1989. Molecular Cloning: A Laboratory Manual. p. A.4. Cold Spring Harbor Laboratory Press, Cold Spring Harbor, New York, USA. 
Sato, S., T. Kaneko, Y. Nakamura, E. Asamizu, T. Kato, and S. Tabata. 2001. Structural analysis of a Lotus japonicus genome. I. Sequence features and mapping of fifty-six TAC clones which cover the $5.4 \mathrm{Mb}$ regions of the genome. DNA Research 8: 311-318.

Savo Sardaro, M.L., M. Atallah, E. Tavakol, L. Russi, and E. Porceddu. 2008. Diversity for AFLP and SSR in natural populations of Lotus corniculatus L. from Italy. Crop Science 48: 1080-1089.

Rajasekar, S., S. Fei, and N.E. Christians. 2006. Analysis of genetic diversity in rough bluegrass determined by RAPD markers. Crop Science 46: 162-167

Squirrel, J., P.M. Hollingsworth, M.L. Woodhead, J. Russell, A.J. Lowe, M. Gibby, and W. Powell. 2003. How much effort is required to isolate nuclear microsatellites from plants? Molecular Ecology 12: 1339-1348.

Steiner, J.J., and G. Garcia de los Santos. 2001. Adaptive ecology of Lotus corniculatus L. geno- types: I. Plant morphology and RAPD marker characterizations. Crop Science 41: 552-563.

Steiner, J.J., and C.J. Poklemba. 1994. Lotus corniculatus classification by seed globulin polypeptides and relationships to accession pedigrees and geographic origin. Crop Science 34:255-260.

Tixier, M.H., P. Sourdille, M. Röder, P. Leroy, and M. Bernard. 1997. Detection of wheat microsatellites using a non radioactive silver-nitrate staining method. J. Genet. Breed. 51:175-177.

Weber, J.L. 1990. Informativeness of human (dCdA)n (dG-dT)n polymorphisms. Genomics 7: 524-530.

Woodgate, K., N. Maxted, and S.J. Bennett. 1999. A generic compectus of forage legumes of the Mediterranean basin. Genetic Resources of Mediterranean pasture. 33:182-226.

Zane, L., L. Bargelloni, and T. Partanello. 2002. Strategies for microsatellite isolation: a review. Molecular Ecology 11: 1-16. 
